\title{
AZ ÓZON NÖVÉNYZETKÁROSÍTÓ HATÁSA
}

\author{
Mészáros Róbert \\ ELTE Meteorológiai Tanszék, 1117 Budapest, Pázmány Péter sétány 1/A \\ e-mail: mrobi@nimbus.elte.hu
}

\section{Bevezetés}

Az ózon $\left(\mathrm{O}_{3}\right)$ a troposzféra egyik legjelentősebb légszennyező anyaga. Szerepet játszik a szén és nitrogén ciklusban, üvegházhatású gázként befolyásolja a Föld-légkör rendszer sugárzásháztartását, a felszínközeli légrétegben pedig károsan hat az emberi egészségre és a növényállományok állapotára. Az ózon másodlagos légszennyező, vagyis közvetlen forrása nincs; a légkörben levegökémiai folyamatok révén keletkezik egyéb légszennyezőkből (Lagzi et al., 2013). A légköri ózonkoncentráció számos folyamat kölcsönhatásaként alakul ki, melyekről az 1. ábra nyújt sematikus képet.

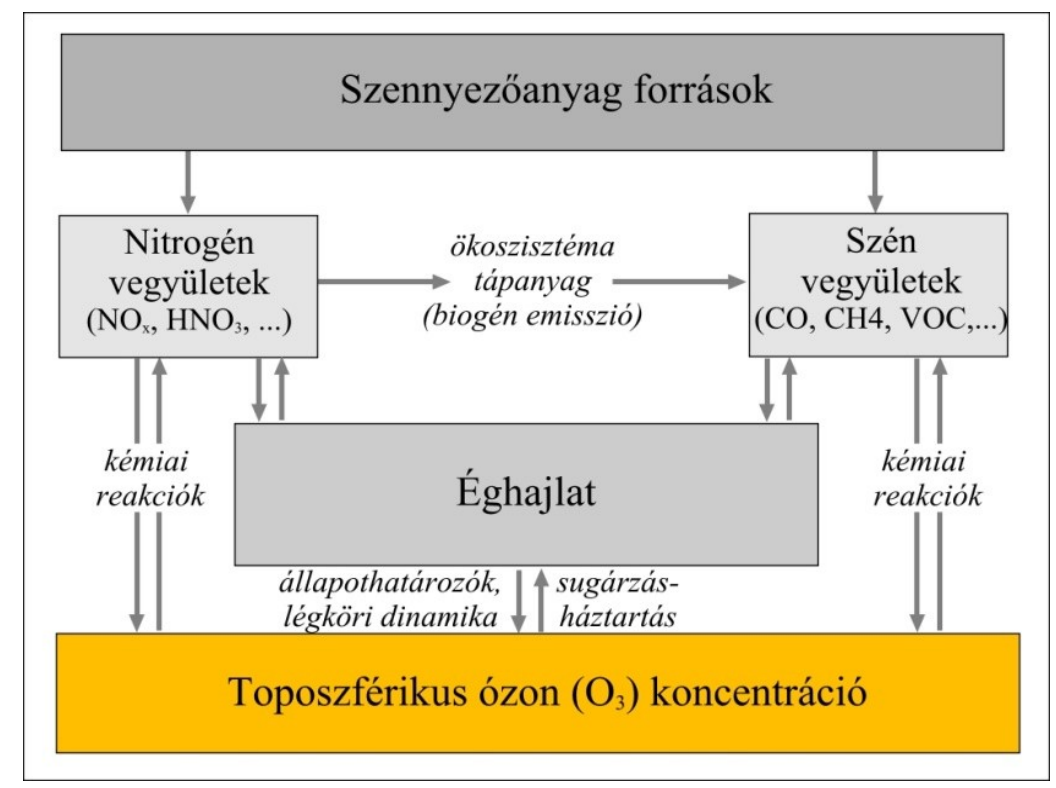

1. ábra: A troposzférikus ózon koncentrációját meghatározó legfontosabb kölcsönhatások

(Monks et al., 2015. alapján).

\section{A troposzférikus ózon mennyisége}

A teljes légköri ózontartalom nagyjából 90\%-a sztratoszférában, míg kb. 10\%-a a troposzférában található. A troposzférikus ózon kevesebb, mint 20\%-a található az alsó troposzférában ( $800 \mathrm{hPa}$ alatt) (Lamarque et al., 2005). Ez, a teljes légköri ózontartalomhoz képest kis mennyiség azonban kiemelt jelentőségű a városi levegőminőség, valamint a különböző felszíneket - elsősorban növényállományokat - érő terhelés szempontjából.

A troposzférában található ózon globális mérlegét különböző kémiai modellekkel írják le. A mérleg egyes tagjainak nagy a bizonytalansága, mert azok erősen függnek a légkör meteorológiai és levegőkémiai állapotától. Összességében, a troposzférikus ózon forrását elsősorban a kémiai folyamatok jelentik, melyek során különböző prekurzor anyagokból $\left(\mathrm{NO}_{\mathrm{x}}, \mathrm{CO}\right.$, 
különféle szerves anyagok, növények terpén és izoprén termelése stb.) keletkezik, illetve kisebb mértékben a sztratoszférából keveredik le az alsóbb rétegekbe. Az ózont elsősorban kémiai nyelök vonják ki a légkörből, de egy jelentős része száraz ülepedéssel kerül a felszínre (1. táblázat). Az ózon nedves ülepedése elhanyagolható, mivel vízben nem, vagy csak nagyon csekély mértékben oldódik.

1. táblázat: Troposzférikus ózonmérleg különböző modellszimulációk alapján.

Az értékek $\mathrm{Tg} \mathrm{O}_{3}$ év $^{-1}$-ben vannak megadva.

\begin{tabular}{llcccc}
\hline & & \multicolumn{2}{c}{ Forrás tagok } & \multicolumn{2}{c}{ Nyelő tagok } \\
\hline \hline & & $\begin{array}{c}\text { Kémiai } \\
\text { keletkezés }\end{array}$ & $\begin{array}{c}\text { Lekeveredés a } \\
\text { sztratoszférából }\end{array}$ & $\begin{array}{l}\text { Kémiai } \\
\text { bomlás }\end{array}$ & $\begin{array}{c}\text { Száraz } \\
\text { ülepedés }\end{array}$ \\
\hline \hline Multi-modell $^{\mathrm{a}}$ & átlag & 3948 & 636 & 3745 & 902 \\
$(1995-2006)$ & szórás & $( \pm 761)$ & $( \pm 273)$ & $( \pm 554)$ & $( \pm 255)$ \\
\hline GEOS-Chem $^{\mathrm{b}}$ & $(1)$ & 4960 & 325 & 4360 & 908 \\
$(2005-2013)$ & $(2)$ & 4630 & 304 & 4090 & 856 \\
& $(3)$ & 5530 & 492 & 4960 & 1040 \\
\hline
\end{tabular}

${ }^{\mathrm{a}}$ Wild (2007); ${ }^{\mathrm{b}} \mathrm{Hu}$ et al. (2017)

(1) GEOS-Chem v10-01 modell, standard futtatás 2012-2013-ra

(2) minimum és (3) maximum értékek különböző meteorológiai és levegőkémiai kezdeti feltételekkel

A korábbi szimulációkhoz képest az újabb modellek alapján jelentősebb a kémiai folyamatok során a troposzférában keletkező és lebomló ózon mennyisége, ami a kémiai folyamatokban szerepet játszó légköri összetevők megnövekedett kibocsátásának tudható be. Ugyanakkor a troposzféra-sztratoszféra ózon kicserélödés globálisan kisebb mértékü az újabb modellszimulációk alapján. A száraz ülepedés mértékében jelentős változás nem tapasztalható.

A troposzférában található össz-ózon mennyisége 345-357 Tg, átlagos tartózkodási ideje 20,9-24,2 nap (Hu et al., 2017). A felszín közelében azonban, szennyezettebb környezetben, az ózon tartózkodási ideje ennél jóval rövidebb - jellemzően néhány óra - ami az ózon légköri ciklusában szerepet játszó vegyületek nagyobb koncentrációjának köszönhető.

\section{A troposzférikus ózon mennyiségének változása}

Az elmúlt évtizedekben az ózon mennyisége a troposzférában - egyben a felszín közelében is - világszerte folyamatosan növekedett (Cooper et al., 2014). Ez számos komoly környezeti problémát okoz, és mind az emberi egészséget (Weschler, 2006), mind a növények müködését (Ainsworth et al., 2012) károsan befolyásolja. A felszínközeli ózon képződésében szerepet játszó, ún. prekurzor vegyületek emissziójának elörejelzett változásai, továbbá levegöminőségi modellszimulációk alapján (1. pl. Emberson et al., 2018) további növekedés következhet be az ózonkoncentráció értékében a 21. században egyes területeken, ami a továbbiakban is károsan befolyásolhatja a természetes és termesztett növényállományok állapotát. Az előrejelzett változás mértéke eltérő a Föld egyes régióiban (Emberson et al., 2018) és attól is függ, hogy milyen mértékben változik az éghajlat. A 2. ábra a troposzféra össz-ózon mennyiségének modellezett értékeit mutatja a múltra és a jövőre vonatkozóan. 


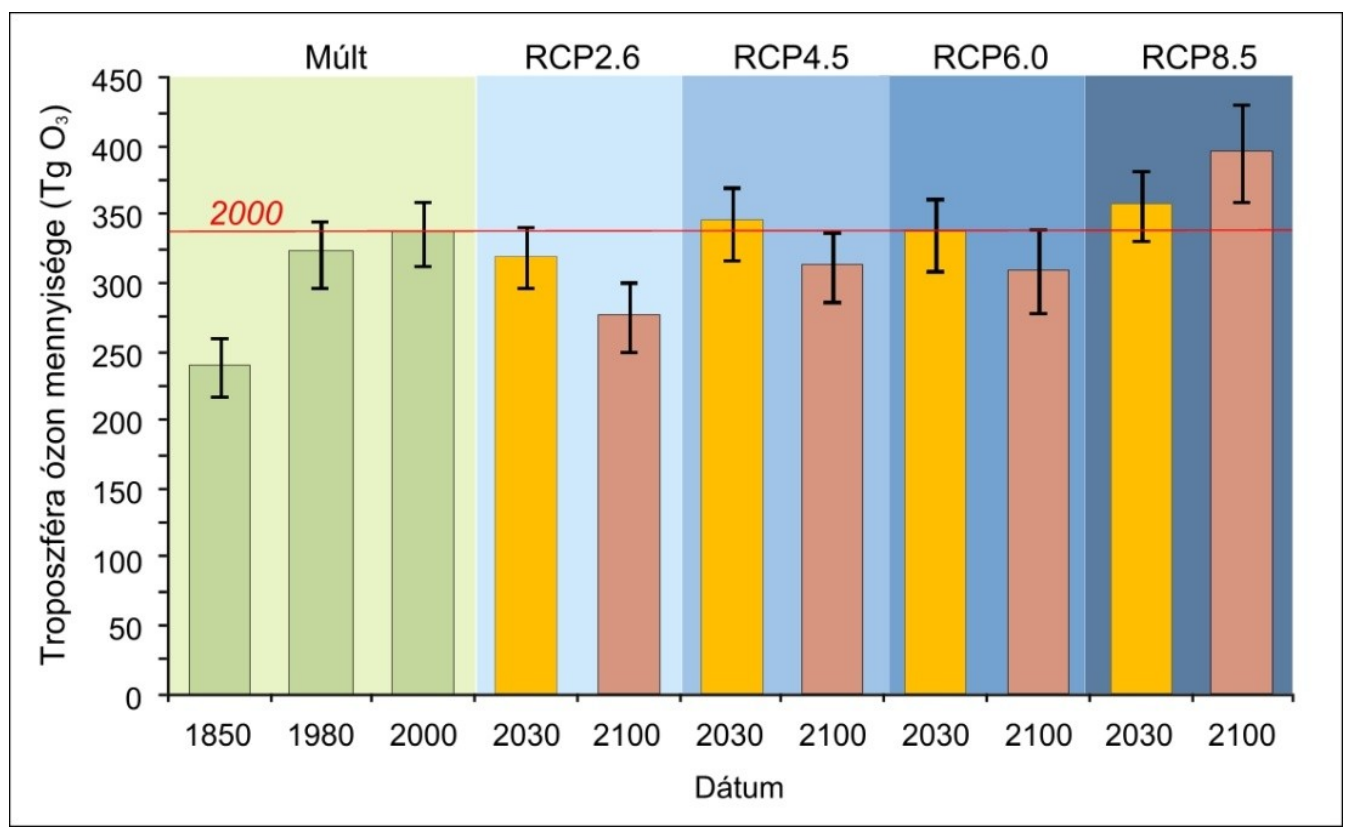

2. ábra: A troposzféra össz-ózon mennyiségének modellezett értékei a múltra, valamint a közeli (2030) és a távoli (2100) jövőre vonatkozóan, különböző klíma szcenáriók (RCP-k) esetére.

A grafikonon feltüntetett értékek az ACCMIP program (Atmospheric Chemistry and Climate Model Intercomparison Project) keretében alkalmazott modellek átlagai, szórásokkal (adatok forrása: Young et al., 2013).

\section{Az ózon növényzetkárosító hatása}

Az ózon többféle módon károsíthatja a növényzetet (Wilkinson et al., 2012), az egyes mezögazdasági és kertészeti növények érzékenysége pedig eltérő az ózonszennyezésre. A megnövekedett ózonkoncentráció látható károsodást okozhat a növényekben, csökkentheti a légcserenyílások (sztómák) müködését, a környezeti feltételektől és a vegetáció típusától függően csökkenő terméshozamot eredményezhet, csökkentheti a fák biomassza növekedését, továbbá befolyásolhatja a növények szén-dioxid megkötő képességét, ami indirekt módon hatást gyakorolhat az éghajlatváltozásra is.

Az ózon elsősorban a légcserenyílásokon (sztómákon) keresztül jut a növénybe. Itt nagyon rövid ideig él (az ózon növényen belüli koncentrációját ezért elhanyagolhatjuk), viszont számos reaktív oxigén forma (ROF) kialakulását eredményezheti (ilynek például a hidrogénperoxid $-\mathrm{H}_{2} \mathrm{O}_{2}$, a szuperoxid-gyök $-\mathrm{O}_{2-}$, vagy a hidroxil-gyök - $\mathrm{HO}$ ). Ezen anyagok reakcióba lépve a növényi sejtekkel, különböző növénykárosító hatást okozhatnak, befolyásolva a sejtek müködését és a növényi anyagcserét. Ráadásul egyes folyamatok visszahatnak a sztómák müködésére is. A tartós, magasabb ózon koncentráció krónikus károkat, míg a rövidebb idejü, de kiugróan magas koncentrációjú ózon epizódok látható sérüléseket okoznak a növényzeten (Emberson at al., 2018). Az ózon által a növényen belül indukált folyamatok és visszacsatolások sematikus képét mutatja a 3. ábra.

Az ózon mennyiségének és károsító hatásának leírására számos mérőszámot alkalmaznak, amiket klímaváltozással kapcsolatos kutatások, az emberi egészségre, valamint a növényállományokra gyakorolt károsító hatások jellemzésére vezettek be (Lefohn et al., 2018). 


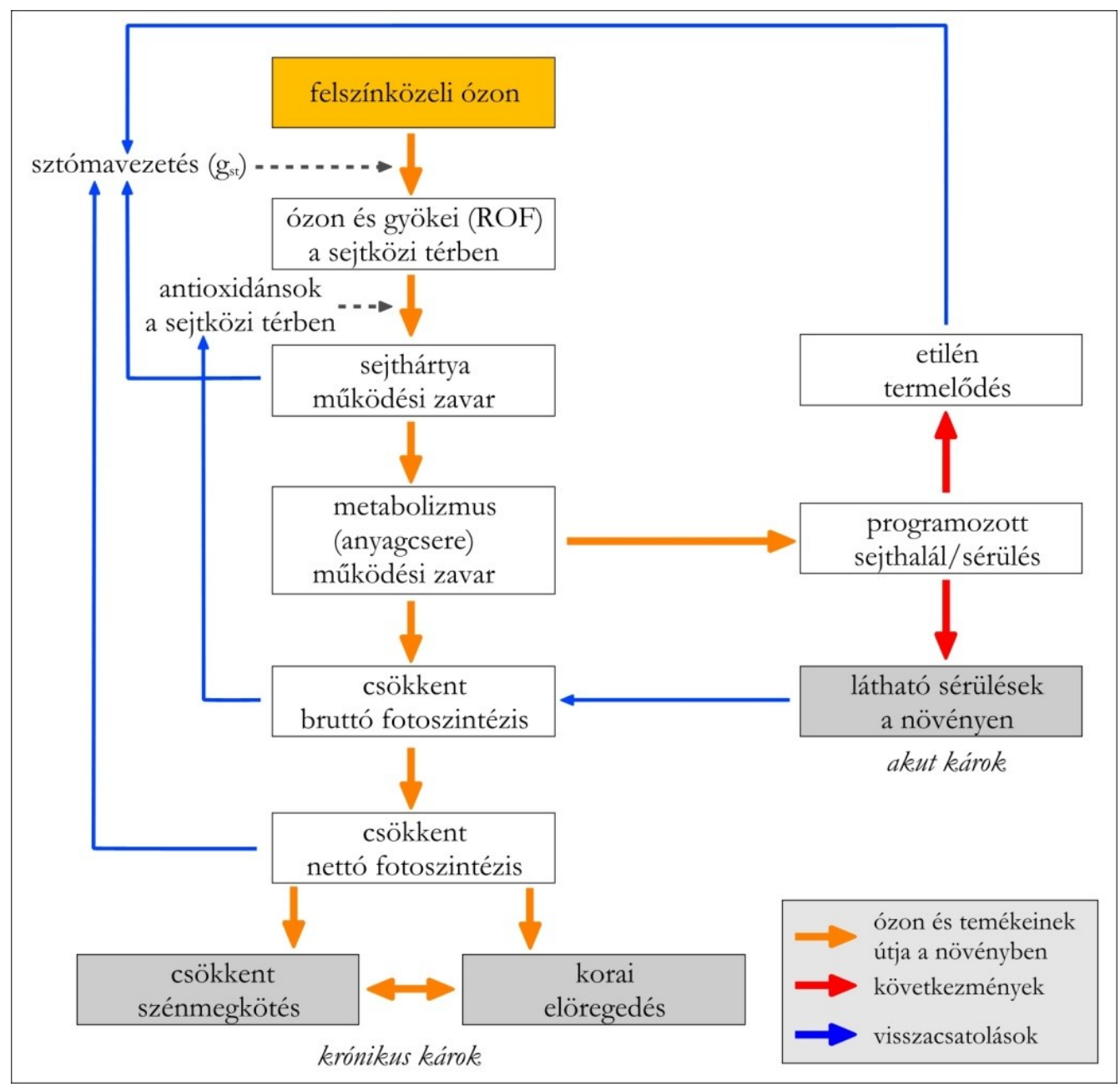

3. ábra: Az ózon és termékeinek (reaktív oxigén formák - ROF) károsító hatásai a növényi sejtekre és anyagcserére (Emberson et al., 2018. alapján).

\section{A növényzetkárosító hatás becslése}

A növényzetkárosító hatást az ózon felszínközeli koncentrációja, vagy fluxusa alapján becsülhetjük. A koncentráció alapú becslés egyszerübb, az ózon felszínközeli koncentrációja alapján általában egy határérték feletti mennyiséget összegeznek egy megadott időszakra (pl. AOTxx, SOMO35). A tényleges károsító hatást azonban jobban jellemzik a fluxus alapú mérőszámok (Musselman et al., 2006). Ilyenek például az ózon teljes fluxusa, a sztómákon keresztüli fluxus, vagy annak valamilyen határérték feletti összege (pl. PODy).

$\mathrm{Az}$ ózon felszínközeli fluxusát mikrometeorológiai mérések, vagy ülepedési modellek segítségével adhatjuk meg. A fluxus arányos a felszíni és a felszínközeli (a mérés szintjén, vagy egy modell legalsó szintjén vett) koncentráció különbségével, de ózon esetén a felszíni (levélen belüli) koncentráció gyakorlatilag zérus, ezért elegendő a felszínközeli koncentráció ismerete. A kapcsolatot a koncentráció és a fluxus között az ülepedési sebesség $\left(\mathrm{v}_{\mathrm{d}}\right)$ adja meg, amit leggyakrabban az ülepedésre ható tényezők (ellenállások) eredőjeként származtatnak (1. pl. Lagzi et al., 2006, Mészáros et al., 2009a).

Az ülepedés leírásában kitüntetett szerepe van a sztómákon keresztüli áramnak, mert a növényzet belsejébe elsősorban a sztómákon keresztül jut be az ózon. Ennek becslésére két alapvető módszer terjedt el, a meteorológiai és a fiziológiai megközelítés. A meteorológiai megközelítés a rövidhullámú sugárzás és környezeti tényezők (léghőmérséklet, légnedvesség, 
talajnedvesség) aktuális értékei által kifejtett stressz-hatások függvényében írja le a sztómákon keresztüli ülepedést gátló sztómaellenállást. A szómák ellenállását az egyes tényezők eltérő mértékben befolyásolják (Mészáros et al., 2006; 2009b, c).

A fiziológiai (növényélettani) megközelítés során a sztómavezetést (a sztómaellenállás reciprokát) leíró modellek a meteorológiai tényezők mellett a növényre vonatkozó mennyiségeket is figyelembe vesznek. Ilyenek például a nettó szén-dioxid megkötés, valamint a széndioxid koncentráció (levél felületen, és levél belsejében meghatározott) értékei (Niyogi és Raman, 1997), vagy az ózon hosszútávú, kumulatív hatását és a növény fenológiai állapotát is figyelembe vevő algoritmusok (Pleijel, 2007).

Az ózon koncentráció és a sztómákon keresztüli ülepedés ismeretében pedig termésbecslömodellekkel a terméskiesés is becsülhető (Emberson et al., 2018; Schauberger et al., 2019).

\section{Köszönetnyilvánítás}

A témában végzett kutatásokat a Nemzeti Kutatási, Fejlesztési és Innovációs Alap K-128805K128818 pályázatai támogatták.

\section{Hivatkozások}

Ainsworth, E.A., Yendrek, C.R., Sitch, S., Collins, W.J., Emberson, L.D., 2012: The Effects of Tropospheric Ozone on Net Primary Productivity and Implications for Climate Change. Annual Review of Plant Biology, 63: 637-661. https://doi.org/10.1146/annurev-arplant042110-103829

Cooper, O.R., Parrish, D.D., Ziemke, J., Balashov, N.V., Cupeiro, M., Galbally, I.E., Gilge, S., Horowitz, L., Jensen, N.R., Lamarque, J.-F., Naik, V., Oltmans, S.J., Schwab, J., Shindell, D.T., Thompson, A.M., Thouret, V., Wang, Y., Zbinden, R.M., 2014: Global distribution and trends of tropospheric ozone: An observation-based review. Elementa, 2: 29. https://doi.org/10.12952/journal.elementa.000029

Emberson, L.A., Pleijel, H., Ainsworth, E.A., van den Berg, M., Ren, W., Osborne, S., Mills, G., Pandey, D., Dentener, F., Büker, P., Ewert, F., Koeble, R.,Van Dingenen, R., 2018: Ozone effects on crops and consideration in crop models. European Journal of Agronomy, 100: 1934. https://doi.org/10.1016/j.eja.2018.06.002

Hu, L., Jacob, D.J., Liu, X., Zhang, Y., Zhang, L., Kim, P.S., Sulprizio, M.P., Yantosca, R.M., 2017: Global budget of tropospheric ozone: Evaluating recent model advances with satellite (OMI), aircraft (IAGOS), and ozonesonde observations. Atmospheric Environment, 167: 323334. http://dx.doi.org/10.1016/j.atmosenv.2017.08.036

Lagzi, I., Mészáros, R., Gelybó, Gy., Leelössy, Á., 2013: Atmospheric Chemistry. ELTE. http://elte.prompt.hu/sites/default/files/tananyagok/AtmosphericChemistry/index.html

Lagzi, I., Mészáros, R., Ács, F., Tomlin, A.S., Haszpra, L., Turányi, T., 2006: Description and evaluation of a coupled Eulerian transport-exchange model: Part I: model development. Idöjárás, 110: 349-363.

Lamarque, J.-F., Hess, P., Emmons, L., Buja, L., Washington, W., Granier, C., 2005: Tropospheric ozone evolution between 1890 and 1990. Journal of Geophysical Research, 110: D08304. http://doi:10.1029/2004JD005537

Lefohn, A.S, Malley, C.S., Smith, L., Wells, B., Hazucha, M., Simon, H., Naik, V., Mills, G., Schultz, M.G., Paoletti, E., De Marco, A., Xu, X., Zhang, L., Wang, T., Neufeld, H.S., Musselman, R.C., Tarasick, D., Brauer, M., Feng, Z., Tang, H., Kobayashi, K., Sicard, P., Solberg, S., Gerosa, G., 2018: Tropospheric ozone assessment report: Global ozone metrics for climate change, human health, and crop/ecosystem research. Elementa, 6: 28. https://doi.org/10.1525/elementa.279 
Mészáros, R., Lagzi, I., Juhász, Á., Szinyei, D., Vincze, Cs., Horányi, A., Kullmann, L. and Tomlin, A.S., 2006: Description and evaluation of a coupled Eulerian transport-exchange model: Part II: sensitivity analysis and application. Idöjárás, 110: 3-4. 365-377.

Mészáros, R., Horváth, L., Weidinger, T., Neftel, A., Nemitz, E., Dämmgen, U., Cellier, P., Loubet, B., 2009a: Masurement and modelling ozone fluxes over a cut and fertilized grassland. Biogeosciences, 6: 1987-1999. https://doi.org/10.5194/bg-6-1987-2009

Mészáros R., Zsély I.Gy., Szinyei, D., Vincze, Cs., Lagzi, I., 2009b: Sensitivity analysis of an ozone deposition model. Atmospheric Environment, 43: 663-672. https://doi.org/10.1016/j.atmosenv.2008.09.058

Mészáros, R., Szinyei, D., Vincze, Cs., Lagzi, I., Turányi,T., Haszpra, L.,Tomlin A.S., 2009c: Effect of the soil wetness state on the stomatal ozone fluxes over Hungary. Int. J. Environment and Pollution, 36: 180-194. https://doi.org/10.1504/IJEP.2009.021825

Monks, P.S., Archibald, A.T., Colette, A., Cooper, O., Coyle, M., Derwent, R., Fowler, D., Granier, C., Law, K.S., Mills, G.E., Stevenson, D.S., Tarasova, O., Thouret, V., von Schneidemesser, E., Sommariva, R., Wild, O., Williams, M.L., 2015: Tropospheric ozone and its precursors from the urban to the global scale from air quality to short-lived climate forcer. Atmos. Chem. Phys., 15: 8889-8973. https://doi.org/10.5194/acp-15-8889-2015

Musselman, R. C., Lefohn, A. S., Massman, W. J., and Heath, R. L. 2006: A critical review and analysis of the use of exposure- and flux-based ozone indices for predicting vegetation effects. Atmospheric Environment, 40: 1869-1888. https://doi.org/10.1016/j.atmosenv.2005.10.064

Niyogi, D.S., Raman, S., 1997: Comparison of Four Different Stomatal Resistance Schemes Using FIFE Observations. J. Appl. Meteor. Climatol, 36: 903-917. https://doi.org/10.1175/15200450(1997)036<0903:COFDSR >2.0.CO;2

Pleijel, H., Danielsson, H., Emberdon, L., Ashmore, M.R., Mills, G., 2007: Ozone risk assessment for agricultural crops in Europe: Further development of stomatal flux and flux-response relationships for European wheat and potato. Atmospheric Environment, 41: 3022-3040. https://10.1016/j.atmosenv.2006.12.002

Schauberger, B., Rolinski, S., Schaphoff, S., Müller, C., 2019: Global historical soybean and wheat yield loss estimates from ozone pollution considering water and temperature as modifying effects. Agricultural and Forest Meteorology, 265: 1-15. https://doi.org/10.1016/j.agrformet.2018.11.004

Young, P.J., Archibald, A.T., Bowman, K.W., Lamarque, J.-F., Naik, V., Stevenson, D.S., Tilmes, S., Voulgarakis, A:, Wild, O., Bergmann, D., Cameron-Smith, P., Cionni, I., Collins, W.J., Dalsøren, S.B., Doherty, R.M:, Eyring, V., Faluvegi, G., Horowitz, L.W., Josse, B., Lee, Y.H:, MacKenzie, I.A., Nagashima, T., Plummer, D.A., Righi, M., Rumbold, S.T., Skeie, R.B., Shindell, D.T., Strode, S.A., Sudo, K., Szopa, S., Zeng, G., 2013: Pre-industrial to end 21st century projections of tropospheric ozone from the Atmospheric Chemistry and Climate Model Intercomparison Project (ACCMIP). Atmos. Chem. Phys., 13: 2063-2090. https://doi:10.5194/acp-13-2063-2013

Weschler, C.J., 2006: Ozone's Impact on Public Health: Contributions from Indoor Exposures to Ozone and Products of Ozone-Initiated Chemistry. Environ Health Perspect, 114(10): 14891496. https://doi.org/10.1289/ehp.9256

Wild, O., 2007: Modelling the global tropospheric ozone budget: exploring the variability in current models. Atmos. Chem. Phys., 7: 2643-2660. https://doi.org/10.5194/acp-7-2643-2007

Wilkinson, S., Mills, G., Illidge, R., Davies, W.J., 2012: How is ozone pollution reducing our food supply? J. Experimental Botany, 63(2): 527-536. https://doi.org/10.1093/jxb/err317

\section{ORCID}

Mészáros R. DD https://orcid.org/0000-0002-0550-9266 